${ }^{1}$ Biotechnology Research Centre, La Trobe University, Bendigo, Victoria, Australia

2 Department of Botany and Microbiology, University of Oklahoma, OK 73019, USA

${ }^{3}$ Deutsche Sammlung von Mikroorganismen und Zellkulturen, D-38124 Braunschweig, Germany

${ }^{4}$ Department of Microbiology and Immunology, University of Melbourne, Parkville, Victoria 3010, Australia

${ }^{5}$ School of Food Biosciences, University of Reading, Reading RG6 6AP, UK

\section{Emended description of the genus Trichococcus, description of Trichococcus collinsii sp. nov., and reclassification of Lactosphaera pasteurii as Trichococcus pasteurii comb. nov. and of Ruminococcus palustris as Trichococcus palustris comb. nov. in the low-G+C Gram-positive bacteria}

\author{
Jian-Rong Liu, ${ }^{1}$ Ralph S. Tanner, ${ }^{2}$ Peter Schumann, ${ }^{3}$ Norbert Weiss, ${ }^{3}$ \\ Christine A. McKenzie, ${ }^{1}$ Peter H. Janssen, ${ }^{4}$ Elizabeth M. Seviour, ${ }^{1}$ \\ Paul A. Lawson, ${ }^{5}$ Toby D. Allen ${ }^{2}$ and Robert J. Seviour ${ }^{1}$
} Author for correspondence: Robert J. Seviour. Tel: +6135444 7459. Fax: +61354447476.
e-mail: r.seviour@latrobe.edu.au

Analyses of 165 rRNA gene sequences, restriction endonuclease digestion fingerprints of 16S-23S intergenic regions, DNA base compositions, fatty-acid profiles, cell-wall chemistry, cell physiology and fermentation end-product composition, along with other biochemical and phenotypic properties, supported the view that Trichococcus flocculiformis Echt ${ }^{\top}$ (DSM 2094'), Lactosphaera pasteurii KoTa2 ${ }^{\top}$ (DSM 2381'), Ruminococcus palustris Z-7189' (DSM 9172') and an isolate named ' Carnococcus allantoicus' NDP were all very similar and should be merged into a single genus. Detailed characterization of strains Ben 77, Ben 200 and Ben 201 described previously as 'Nostocoida limicola' I, a filamentous bacterium which causes bulking in activated sludge systems, revealed that these strains also belonged to the same genus as $T$. flocculiformis Echt', L. pasteurii KoTa2 ${ }^{\top}$, R. palustris Z-7189' and ' C. allantoicus' NDP. In fact, their shared properties suggested that these strains all belonged to a single species. However, DNA-DNA hybridization data indicated that $T$. flocculiformis Echt', all of the ' $N$. limicola' I isolates and ' C. allantoicus' NDP belonged to the same species, whereas $L$. pasteurii KoTa2 ${ }^{\top}$, R. palustris Z-7189' and two new isolates, 37AN3 ${ }^{* T}$ and 45AN2, represented three distinct species within the same genus. The priority of the genus name Trichococcus is established and since its validation predates the description of the genus Lactosphaera this name should take precedence. Under certain culture conditions, all of the strains mentioned above could produce chains of cocci. Furthermore, the morphology of $T$. flocculiformis Echt ${ }^{\top}$ could change to a nonfilamentous form on certain media. This study proposes that the above strains be reclassified as members of the genus Trichococcus as four species, namely Trichococcus flocculiformis emend. (type strain Echt ${ }^{\top}=$ DSM 2094'), Tricho-

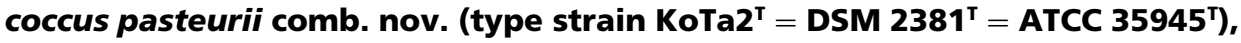
Trichococcus collinsii sp. nov. (type strain 37AN3 ${ }^{* \top}=$ DSM $14526^{\top}=$ ATCC BAA- $^{\top}$

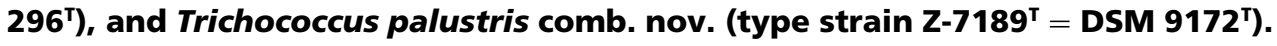

Keywords: Lactosphaera pasteurii, Trichococcus flocculiformis, ' Nostocoida limicola' I, 'Carnococcus allantoicus', Ruminococcus palustris

The GenBank accession numbers for the 16S rRNA sequences reported in this paper are AF244371, AJ306611 and AJ306612 for Trichococcus flocculiformis Ben 200 Trichococcus flocculiformis Echt ${ }^{\top}$ and Trichococcus collinsii 37AN3 ${ }^{* \top}$, respectively. 


\section{INTRODUCTION}

Scheff et al. (1984a) described a filamentous bacterium responsible for bulking in activated sludge plants in Germany. This filamentous bacterium, consisting of cocci in chains, was descriptively named Trichococcus flocculiformis, a name which was validated in 1984 (Scheff et al., 1984b). Surprisingly, until recently, this bacterium had not been reported as a bulking agent isolated from sludge plants in other parts of the world. This is possibly because its description was not included in the manuals (Eikelboom, 2000; Jenkins et $a l ., 1993)$ widely used in the wastewater industry to 'identify' such filamentous bacteria. Subsequently, $16 \mathrm{~S}$ rRNA sequence analysis has revealed that $T$. flocculiformis $\mathrm{Echt}^{\mathrm{T}}$ is almost identical to Lactosphaera pasteurii KoTa2 ${ }^{\mathrm{T}}$ (Stackebrandt et al., 1999), a nonfilamentous, aerotolerant, lactate-producing coccus belonging to the low-G $+\mathrm{C}$ Gram-positive bacteria, originally isolated from anoxic digester sludge (Janssen et al., 1995). Liu et al. (2000) showed that, on the basis of similarities in their 16S rRNA sequences, some isolates of a bulking filamentous bacterium they described as 'Nostocoida limicola' I (van Veen, 1973; Jenkins et al., 1993), from Australia and the Czech Republic, were also very closely related to $T$. flocculiformis $\mathrm{Echt}^{\mathrm{T}}$, whose morphology they can resemble. This study describes an extensive characterization of these bacteria, and the data presented convincingly suggest that, despite often considerable differences in their morphologies, these bacteria should all be grouped into a single genus. This genus should also contain 'Carnococcus allantoicus' NDP (R. S. Tanner, unpublished data), a strain isolated from duck-pond sediment as a non-filamentous organism. However, DNA-DNA hybridization data presented here suggest that L. pasteurii $\mathrm{KoTa}^{\mathrm{T}}$ should be placed into a separate species to the other strains. On the basis of their characteristics, Ruminococcus palustris Z-7189 ${ }^{\mathrm{T}}$, isolated from a swamp (Zhilina et al., 1995), and two previously undescribed isolates, $37 \mathrm{AN} 3{ }^{* \mathrm{~T}}$ and $45 \mathrm{AN} 2$, obtained from a hydrocarbon-spill site (Gieg et al., 1999), are also considered to represent new species of the same genus. The genus name Trichococcus takes priority over Lactosphaera according to the Bacteriological Code (1990 revision) and, furthermore, is suited for circumscription of the morphology of these strains since, under some growth conditions and in some media, all can grow as chains of cocci.

\section{METHODS}

Strains and culture conditions. The isolates used in this study are listed in Table 1. Strains $37 \mathrm{AN}^{* \mathrm{~T}}$ and $45 \mathrm{AN} 2$, isolated from a gas-condensate-contaminated soil in Colorado (Gieg et al., 1999), were cultured using half-strength tryptic soy broth (Difco). ' C. allantoicus' NDP, isolated from a duckpond sediment, was cultured in an allantoin-based medium with the mineral salts, trace metals and vitamin solution of Tanner (1997) supplemented with yeast extract $\left(1 \mathrm{~g} \mathrm{l}^{-1}\right)$ and allantoin $\left(5 \mathrm{~g} \mathrm{l}^{-1}\right)$, and it was incubated under anaerobic conditions. 'C. allantoicus' NDP is very similar to an isolate,
'Streptococcus allantoicus', described by Barker (1943). All cultures were maintained at $-80^{\circ} \mathrm{C}$. In some experiments, where the influence of growth conditions on cell morphology was investigated, the following media were used: R2A broth and agar (Reasoner \& Geldreich, 1985); SR2A broth and agar (Liu et al., 2001); SCY agar (van Veen, 1973); and M69 agar (Scheff et al., 1984a). All of the cultures were incubated at $26^{\circ} \mathrm{C}$, sometimes with shaking (180 r.p.m.) unless otherwise stated.

Phenotypic characterization. Strains grown on R2A agar were characterized using the BIOLOG system to obtain their substrate utilization patterns and the API ZYM system to obtain their enzyme profiles, following the manufacturers' instructions for both systems. The abilities of the strains to grow aerobically or anaerobically on other substrates, including allantoin, L-tartrate, citrate, DL-malate, ethanol, succinate, fumarate, L-glutamate, glycerol and crotonate, were determined by using the allantoin-based isolation medium described above in which the allantoin was replaced by the test substrate at $5 \mathrm{~g} \mathrm{l}^{-1}$, or by using the methods described by Janssen et al. (1995) and incorporating appropriate controls. Fatty acid methyl ester (FAME) analyses were performed by Microcheck, using cells grown on tryptic soy agar at room temperature for 3 days. The derivatization and analysis of the fatty acids was done using the methods of Miller (1982) and Sassar (1990). The fatty acid data of Zhilina et al. (1995) were used here for R. palustris Z-7189 ${ }^{\mathrm{T}}$. The peptidoglycan type of the strains was determined according to the protocol of Schumann et al. (1997). Cells were prepared and viewed under a scanning electron microscope, using the methods described by Liu et al. (2000).

Fermentative behaviour of strains. The sulfide-reduced, bicarbonate-buffered growth medium FM, described by Janssen et al. (1997), was used for these studies. Medium FH contained the salts and trace elements in FM, except that $0.5 \mathrm{~g}$ of $\mathrm{MgSO}_{4} \cdot 7 \mathrm{H}_{2} \mathrm{O}$ was used instead of $\mathrm{MgCl}_{2} \cdot 6 \mathrm{H}_{2} \mathrm{O}$, sulfide and bicarbonate were omitted from the medium, and the medium was buffered with $10 \mathrm{mM}$ HEPES. The initial pH was $7 \cdot 3$, adjusted with $\mathrm{NaOH}$. Growth substrates and yeast extract were added to FM and $\mathrm{FH}$, as required, from filter-sterilized stock solutions. Aerobically incubated cultures were grown in $10 \mathrm{ml}$ aliquots in screw-capped bottles $(40 \mathrm{ml})$ with loosened lids, which were shaken at 150 r.p.m. Cultures incubated anoxically, also in $10 \mathrm{ml}$ aliquots in screw-capped bottles $(40 \mathrm{ml})$ with loosened lids, were grown in anaerobic jars with GasPak Plus sachets (Becton Dickinson) to remove $\mathrm{O}_{2}$. Cultures grown under strictly anaerobic conditions in FM were in $50 \mathrm{ml}$ aliquots in completely filled glass screw-capped bottles with rubber-lined metal lids. Bulk cultures for dry mass determinations and the detection of cytochromes were grown statically under air in $200 \mathrm{ml}$ aliquots of $\mathrm{FH}$ supplemented with $10 \mathrm{mM}$ glucose $1^{-1}$ and $0 \cdot 1 \mathrm{~g}$ yeast extract $1^{-1}$. Inocula were $1 \%(\mathrm{v} / \mathrm{v})$, and incubations were done at $25^{\circ} \mathrm{C}$. Yeast extract was routinely added to all media at $0 \cdot 1 \mathrm{~g} \mathrm{l}^{-1}$.

Fermentation products and balances. The utilization of growth substrates and the production of organic acids and alcohols were determined by HPLC (Ehrlich et al., 1981) using a refractive index detector. The isomeric form of lactic acid was determined enzymically (Bergmeyer, 1974). Dry mass growth yields were calculated from culture densities measured at $600 \mathrm{~nm}$ in a $10 \mathrm{~mm}$ cuvette using a gravimetrically determined conversion factor obtained from washed $(25 \mathrm{mM}$ ammonium acetate) cell pellets harvested from four $200 \mathrm{ml}$ cultures by centrifugation and dried to a 
Table 1. Summary of main discriminatory phenotypic and chemotaxonomic characters of strains used in this study

Strains: 1, strain Ben 200; 2, strain Ben 201; 3, strain Ben 77; 4, T. flocculiformis Echt ${ }^{\mathrm{T}} ; 5$, L. pasteurii $\mathrm{KoTa}^{\mathrm{T}}$; 6, 'C. allantoicus' NDP; 7, R. palustris Z-7189 ${ }^{\mathrm{T}}$; 8, strain $37 \mathrm{AN} 3{ }^{* \mathrm{~T}} ; 9$, strain $45 \mathrm{AN} 2$. ?, Not determined.

\begin{tabular}{|c|c|c|c|c|c|c|c|c|c|}
\hline Source & $\begin{array}{l}\text { Activated } \\
\text { sludge }\end{array}$ & $\begin{array}{l}\text { Activated } \\
\text { sludge }\end{array}$ & $\begin{array}{l}\text { Activated } \\
\text { sludge }\end{array}$ & $\begin{array}{l}\text { Activated } \\
\text { sludge }\end{array}$ & Septic pit & $\begin{array}{l}\text { Duck-pond } \\
\text { sediment }\end{array}$ & Swamp & $\begin{array}{l}\text { Hydrocarbon-spill } \\
\text { site }\end{array}$ & Spill \\
\hline Temperature range & 4 to $<37^{\circ} \mathrm{C}$ & Ben $200^{*}$ & $?$ & 4 to $<40{ }^{\circ} \mathrm{C}$ & $0-42{ }^{\circ} \mathrm{C}$ & $>7$ to $<46^{\circ} \mathrm{C}$ & $0-33^{\circ} \mathrm{C}$ & $>7$ to $<36^{\circ} \mathrm{C}$ & $>7$ to $<36{ }^{\circ} \mathrm{C}$ \\
\hline (optimum) & $\left(12-30{ }^{\circ} \mathrm{C}\right)$ & Ben $200^{*}$ & $?$ & $\left(25-30{ }^{\circ} \mathrm{C}\right)$ & $\left(25-30{ }^{\circ} \mathrm{C}\right)$ & $\left(23-36{ }^{\circ} \mathrm{C}\right)$ & $?$ & $\left(23-30{ }^{\circ} \mathrm{C}\right)$ & $\left(23-30{ }^{\circ} \mathrm{C}\right)$ \\
\hline $\begin{array}{l}\mathrm{pH} \text { range } \\
\text { (optimum) }\end{array}$ & $6-10(?)$ & Ben $200 *(?)$ & $?$ & $5 \cdot 8-9 \cdot 0(8 \cdot 0)$ & $\begin{array}{c}5 \cdot 5-9 \cdot 0 \\
(?)\end{array}$ & $6-9(8 \cdot 0)$ & $\begin{array}{c}6 \cdot 2-8 \cdot 4 \\
(7 \cdot 5)\end{array}$ & $6-9(7 \cdot 5)$ & $6-9(7 \cdot 5)$ \\
\hline Citrate & - & + & - & + & + & + & ? & + & + \\
\hline L-Malate & - & - & - & - & + & + & - & + & + \\
\hline Allantoin & - & + & - & - & - & + & ? & + & + \\
\hline L-Tartrate & - & - & - & - & + & - & $?$ & + & + \\
\hline \multicolumn{10}{|l|}{ Acid from: } \\
\hline Inositol & + & + & + & + & + & + & - & + & - \\
\hline Mannitol & + & + & + & + & + & - & + & + & + \\
\hline Urease & + & + & - & - & - & - & - & - & - \\
\hline
\end{tabular}

* Some data from Liu et al. (2000).

$\dagger$ Data from Scheff et al. (1984a).

\$ Some data from Janssen et al. (1995).

$\S$ Data from Zhilina et al. (1995). 
constant mass at $105^{\circ} \mathrm{C}$. D-Fructose-1,6-bisphosphate-activated lactate dehydrogenase activity was measured at $30^{\circ} \mathrm{C}$ as described by Lamed \& Zeikus (1980). D-Fructose-1,6bisphosphate-independent lactate dehydrogenase activity was measured by the same method, but with the omission of D-fructose 1,6-bisphosphate. The presence of cytochromes was assayed spectrophotometrically according to Janssen (1998).

DNA analysis of strains. DNA base composition determinations and DNA-DNA hybridization experiments were carried out using the methods described by Maszenan et al. (2000).

Fingerprinting of the 16S-23S intergenic spacer region. DNA was extracted and purified from pure cultures using a slight modification of the method of Bond et al. (1995). In the absence of any sequence information on this region in these bacteria, the PCR primers selected to amplify the $16 \mathrm{~S}-23 \mathrm{~S}$ region were the primers 2 forward and 7 reverse of Gürtler \& Stanisich (1996). The PCR mix used was as follows. Fifty microlitres of reaction mix containing PCR reaction buffer (Applied Biosystems), $1 \mu \mathrm{M}$ of each primer, $1.5 \mathrm{mM} \mathrm{MgCl}$, $200 \mu \mathrm{M}$ of each dNTP (Roche Diagnostics), 5\% (v/v) DMSO and 2.5 U AmpliTaq Gold (Applied Biosystems). DNA was amplified by using a GeneAmp 2400 PCR system (Applied Biosystems) with the following protocol: $10 \mathrm{~min}$ activation at $94{ }^{\circ} \mathrm{C}$ followed by 30 cycles of denaturation $\left(1 \mathrm{~min}\right.$ at $\left.94{ }^{\circ} \mathrm{C}\right)$, annealing $\left(1 \mathrm{~min}\right.$ at $\left.53^{\circ} \mathrm{C}\right)$ and extension $\left(4 \mathrm{~min}\right.$ at $72{ }^{\circ} \mathrm{C}$ ), followed by a further $10 \mathrm{~min}$ at $72{ }^{\circ} \mathrm{C}$ for the final extension. Amplified products were visualized by running them on agarose gels $[1 \%$ SeaKem agarose (FMC) in Tris/borate buffer $(0.045 \mathrm{M}$ Tris/borate, 0.001 M EDTA, $\mathrm{pH}$ 8.0)] and then staining the gels with ethidium bromide. Sau3AI, MspI and BstUI (5-10 U of each; all from New England Biolabs) were used to digest the PCR products. Digests were carried out at 37 or $60^{\circ} \mathrm{C}$ for $4 \mathrm{~h}$ in a reaction volume of $20 \mu \mathrm{l}$, using the recommended buffers for each enzyme. The digest products were then analysed by gel electrophoresis [3\% New Sieve agarose (FMC) in Tris/ borate buffer containing ethidium bromide] followed by visualization under UV light, and the gels were photographed using Polaroid 665 film.

Phylogenetic analysis of strains. Phylogenetic determination was performed by comparative $16 \mathrm{~S}$ rRNA gene sequence analysis. A large fragment of the $16 \mathrm{~S}$ rRNA gene (corresponding to positions $30-1521$ of the E. coli $16 \mathrm{~S}$ rRNA gene) was amplified from strains Ben 200, Echt ${ }^{T}$ and $37 \mathrm{AN} 3{ }^{* \mathrm{~T}}$ by PCR, using conserved primers close to the $3^{\prime}$ and $5^{\prime}$ ends of the gene. The PCR products were directly sequenced using a dideoxy terminator cycle sequencing kit (Applied Biosystems) and an automated DNA sequencer (model 373A; Applied Biosystems). The closest known relatives of these strains were determined by performing a database search using the program FASTA of the Genetics Computer Group package (Lipman \& Pearson, 1985). These sequences and those of other known related strains were retrieved from the EMBL or RDP data libraries and aligned with the newly determined sequences using the program DNATOOLS (Rasmussen, 1995). The resulting multiple-sequence alignment was corrected manually and approximately 100 bases at the $5^{\prime}$ end of the rRNA were omitted from further analyses because of alignment ambiguities using the program GENEDOC (Nicholas et al., 1997). Pairwise evolutionary distances were then computed from a continuous stretch of 1320 bases and a distance matrix was calculated by using DNADIST (using the Kimura-2 correction parameter). A phylogenetic tree was constructed according to the neighbour-joining method with the program NEIGHBOR (Felsenstein, 1989). The stability of the groupings was estimated by bootstrap analysis (500 replications) using the programs SEQBOOT, DNADIST, NEIGHBOR and CONSENSE (Felsenstein, 1989). The 16S rRNA gene sequences of Ben 200, T. flocculiformis $\mathrm{Echt}^{\mathrm{T}}$ and $37 \mathrm{AN} 3{ }^{* \mathrm{~T}}$ have been deposited in GenBank under accession numbers AF244371, AJ306611 and AJ306612, respectively.

\section{RESULTS}

\section{Morphology of the isolates}

All of the strains examined in this study were pleiomorphic, often with cell forms different to those expected from their original descriptions. These morphological variations are illustrated in Figs 1 and 2. For example, although T. flocculiformis $\mathrm{Echt}^{\mathrm{T}}$ grew as regular cocci in chains, as described by Scheff et al. (1984a), on most of the media (e.g. SR2A agar) (Fig. 1a), it grew on R2A agar as much larger tapered rod-shaped cells, which often occurred in pairs (Fig. 1b). A similar morphology was seen for L. pasteurii KoTa $2^{\mathrm{T}}$ when it was (Fig. 1d) grown on R2A agar, but it grew as regular cocci on SR2A agar (Fig. 1c), in accordance with the description of Janssen et al. (1995). 'C. allantoicus' NDP had a similar appearance when grown on these two media, displaying tapered cells in pairs (Fig. 1e, f), whereas strains $37 \mathrm{AN} 3 * \mathrm{~T}$ and $45 \mathrm{AN} 2$ grew quite differently on R2A and SR2A agar (Fig. 1g-j). Strain $37 \mathrm{AN} 3 * \mathrm{~T}$ appeared as swollen, often tapered, paired, irregular cells on both SR2A and R2A agar, but its cells were much larger on the latter medium (Fig. $1 \mathrm{~g}, \mathrm{~h})$. Strain $45 \mathrm{AN} 2$ grew as more regular single or paired cocci on SR2A agar, whereas on R2A agar irregular, much larger coccoid or tapered cells, often arranged in pairs were seen (Fig. 1i, j). Ben 200 changed from regular cocci in chains on SR2A agar (Fig. 1k) to highly irregular pleiomorphic cells in chains on R2A agar (Fig. 11).

Similar changes were seen in the above cultures grown in R2A broth when compared to SR2A broth, whether these media were shaken or not. Examples of these differences, which were often substantial, are shown in Figs 2(a-1). Again, the Ben strains were especially pleiomorphic. For example, in R2A broth, Ben 200 produced irregular swollen cells under static conditions (Fig. 2a), but paired cocci were seen when the cultures were shaken (Fig. 2b). Equally striking were the change in appearance of $L$. pasteurii $\mathrm{KoTa} 2^{\mathrm{T}}$, which in R2A broth produced short chains of coccoid and irregular cells (Fig. 2e,f); this change was also seen with $37 \mathrm{AN} 3 * \mathrm{~T}$ (Fig. $2 \mathrm{i}, \mathrm{j}$ ) and $45 \mathrm{AN} 2$ when they were grown in R2A broth (Fig. 2k, 1). Highly irregular cells also were produced by ' $C$. allantoicus' NDP in R2A broth (Fig. 2g, h), especially when the culture was shaken (Fig. 2h). T. flocculiformis Echt $^{\mathrm{T}}$ grew in a regular filamentous form in both R2A and SR2A broths under shaken and static conditions (Fig. 2c, d).

The possible pleiomorphic nature of $R$. palustris Z$7189^{\mathrm{T}}$ was not studied in such detail but, in agreement with the observations of Zhilina et al. (1995), its cells 

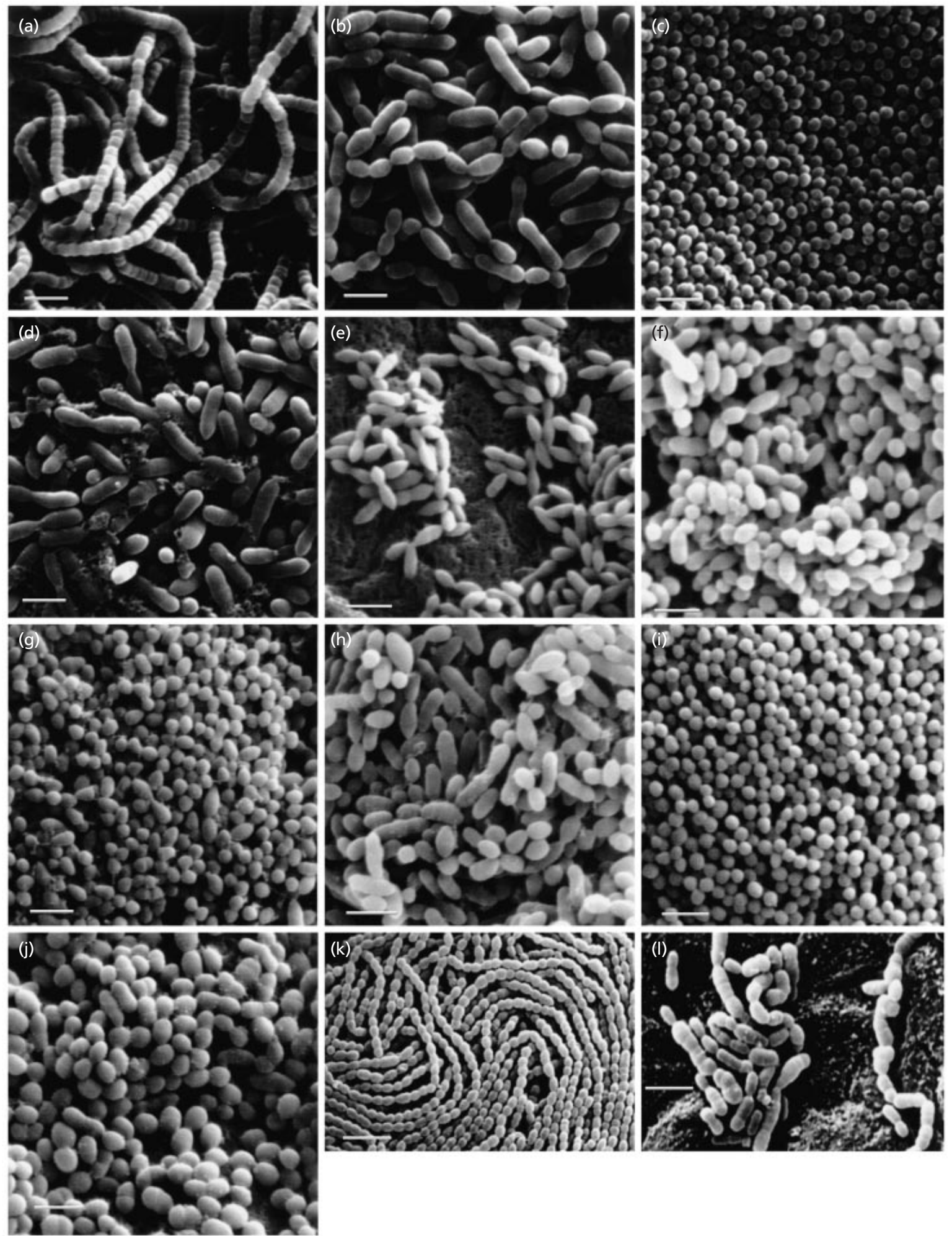

Fig. 1. Scanning electron micrographs of $T$. flocculiformis $\operatorname{Echt}^{\top}(a, b)$, L. pasteurii $\operatorname{KoTa}^{\top}(c, d)$, 'C. allantoicus' NDP (e, f), strain 37AN3*T $(\mathrm{g}, \mathrm{h})$, strain 45AN2 $(\mathrm{i}, \mathrm{j})$ and strain Ben $200(\mathrm{k}, \mathrm{l})$ growing on SR2A agar $(a, c, e, g, i, k)$ and on R2A agar $(b, d, f, h, j, l)$, showing the morphological variations in cell shape and arrangement of these organisms. Further details are given in the text. Bar, $2 \mu \mathrm{m}$ for all, except for $(k)$ in which the bar is $4 \mu \mathrm{m}$. 

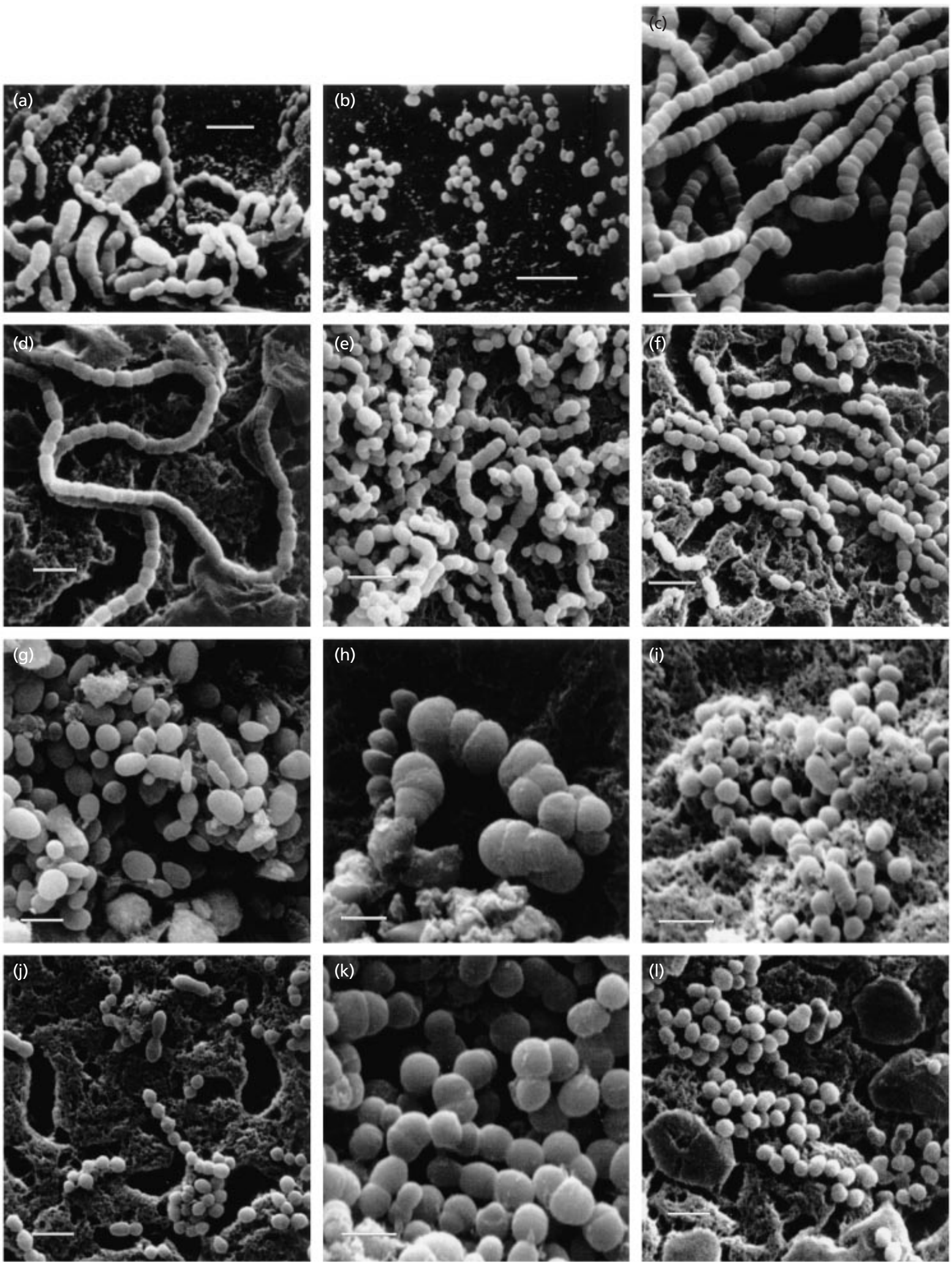

Fig. 2. Scanning electron micrographs of strain Ben 200 (a, b), T. flocculiformis $\operatorname{Echt}^{\top}$ (c, d), L. pasteurii $\mathrm{KoTa} 2^{\top}(\mathrm{e}, \mathrm{f})$, 'C. allantoicus' NDP $(g, h)$, strain 37AN3*T $(l, j)$ and strain 45AN2 $(k, l)$ growing in R2A broth without shaking (Fig. $1 a, c, e, g, l, k$ ) and with shaking (Fig. $1 b, d, f, h, j, l)$, showing the variations in the cell shape and arrangements of these strains. Further details are given in text. Bar, $2 \mu \mathrm{m}$ for all, except for (g) and (j) in which the bars are $3 \mu \mathrm{m}$. 
Table 2. Differences in substrate utilization patterns between isolates determined using the BIOLOG system

Strains: 1, strain Ben 77; 2, strain Ben 200; 3, strain Ben 201; 4, T. flocculiformis Echt $^{\mathrm{T}}$; 5, L. pasteurii KoTa2 ${ }^{\mathrm{T}}$; 6, R. palustris Z-7189 $;$ 7, 'C. allantoicus' NDP; 8, strain 45AN2; 9, strain 37AN3*T. All other substrates examined gave the same results for all strains. + , Positive; -, negative.

\begin{tabular}{|llllllllll|}
\hline Substrate & $\mathbf{1}$ & $\mathbf{2}$ & $\mathbf{3}$ & $\mathbf{4}$ & $\mathbf{5}$ & $\mathbf{6}$ & $\mathbf{7}$ & $\mathbf{8}$ & $\mathbf{9}$ \\
\hline Cellobiose & - & + & + & + & + & + & + & + & + \\
D-Galactose & - & + & + & + & + & - & + & + & + \\
Gentiobiose & - & + & + & + & + & + & + & + & + \\
$\alpha$-D-Lactose & - & + & - & + & + & - & + & + & - \\
Lactulose & - & + & - & + & + & - & + & - & - \\
Maltose & + & + & + & + & + & - & + & + & - \\
Maltotriose & + & + & + & + & + & - & + & + & + \\
D-Mannitol & - & - & - & - & - & - & + & + & - \\
D-Melezitose & - & - & - & - & - & - & - & + & - \\
Methyl $\alpha$-D-galactoside & - & - & - & - & - & - & + & - & - \\
Methyl $\beta$-D-galactoside & - & - & - & - & - & + & + & - & - \\
3-Methyl glucose & - & + & + & - & - & - & - & - & - \\
Methyl $\beta$-D-glucoside & + & + & + & + & + & - & + & + & + \\
Palatinose & - & + & + & + & + & - & + & + & + \\
D-Psicose & - & + & + & + & + & + & + & + & + \\
D-Raffinose & - & + & + & - & - & - & + & + & + \\
D-Ribose & - & - & - & - & - & - & + & + & - \\
Stachyose & - & - & - & - & - & - & + & - & - \\
D-Trehalose & + & + & + & + & + & - & + & + & + \\
Turanose & - & + & + & + & + & - & - & - & - \\
L-Lactic acid & - & - & - & - & - & + & - & - & - \\
Methyl pyruvate & - & + & + & + & + & + & + & + & + \\
Pyruvate & - & + & + & + & + & + & + & + & + \\
Adenosine & - & + & - & + & + & - & - & + & + \\
2'-Deoxyadenosine & - & + & - & + & + & - & - & - & - \\
Uridine & - & + & - & + & + & - & - & + & - \\
Thymidine & - & + & - & + & + & - & - & - & - \\
\hline
\end{tabular}

were oval with tapered ends and showed a tendency to form pairs or short chains on R2A agar.

\section{Phenotypic properties}

All of the strains in this study were very similar phenotypically. They were all oxidase and catalase negative, $\mathrm{H}_{2} \mathrm{~S}$ negative and ornithine decarboxylase negative. All grew with glucose (both oxically and anoxically - see below), produced acid from sucrose and lactose metabolism and all, except for $R$. palustris $\mathrm{Z}-7189^{\mathrm{T}}$, could grow with xylose, rhamnose and Darabinose. None of the strains grew in the presence of ethanol and all of the strains, except for Ben 77, $R$. palustris Z-7189 $9^{\mathrm{T}}$ and Ben 200 , grew with citrate. Only Ben 201, 'C . allantoicus' NDP and strains 37AN3*T and 45AN2 grew in the presence of allantoin, whereas L. pasteurii $\mathrm{KoTa}_{2}{ }^{\mathrm{T}}$ and strains $37 \mathrm{AN} 3{ }^{* \mathrm{~T}}$ and $45 \mathrm{AN} 2$ alone grew with L-tartrate (Table 1). The results obtained with the BIOLOG system showed that all of the strains assimilated arbutin, cellobiose, D-fructose, $\alpha$-D-glucose, D-mannose, salicin, sucrose and pyruvate. None of the following substrates were utilized ac- cording to the results of BIOLOG screening: $\beta$ cyclodextrin, inulin, Tween 40 , Tween 80 , L-arabinose, D-arabitol, L-fucose, D-galacturonic acid, D-gluconic acid, myo-inositol, methyl $\alpha$-D-glucoside, methyl $\alpha$ D-mannoside, sedoheptulosan, D-sorbitol, D-tagatose, xylitol, D-xylose, acetic acid, $\alpha$-hydroxybutyrate, $\beta$-hydroxybutyrate, $\gamma$-hydroxybutyrate, $\beta$-hydroxyphenylacetate, 2-oxoglutarate, 2-oxovalerate, lactamide, Dlactic acid methyl ester, L-lactic acid, D-malic acid, Lmalic acid, monomethylsuccinic acid, propionic acid, succinamic acid, $N$-acetylglutamic acid, alaninamide, D-alanine, L-alanine, L-alanylglycine, L-asparagine, Lglutamic acid, glycyl-L-glutamic acid, L-pyroglutamic acid, L-serine, putrescine, 2,3-butanediol, glycerol, inosine, thymidine, adenosine 5'-monophosphate, thymidine 5'-monophosphate, uridine 5'-monophosphate, fructose 6-phosphate, glucose 1-phosphate, glucose 6-phosphate, DL- $\alpha$-glycerol phosphate. For some substrates (e.g. L-rhamnose, D-xylose, L-malate, citrate and salicin) different results were obtained with the BIOLOG system from those obtained from the growth experiments using conventional methods. The BIOLOG substrate utilization patterns that were 
Table 3. API ZYM profiles showing differences in detectable enzymes in strains

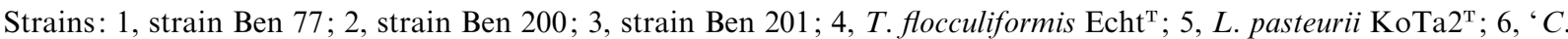
allantoicus' NDP; 7, R. palustris Z-7189 $;$; , strain 37AN3*T; 9 , strain 45AN2. 0, No activity; $1-5$ indicate relative levels of activity, with 1 being the least active and 5 being the most active.

\begin{tabular}{|llllllllll|}
\hline Enzyme & $\mathbf{1}$ & $\mathbf{2}$ & $\mathbf{3}$ & $\mathbf{4}$ & $\mathbf{5}$ & $\mathbf{6}$ & $\mathbf{7}$ & $\mathbf{8}$ & $\mathbf{9}$ \\
\hline Alkaline phosphatase & 0 & 1 & 0 & 0 & 0 & 0 & 0 & 1 & 0 \\
Esterase (C4) & 0 & 3 & 2 & 1 & 1 & 1 & 1 & 1 & 1 \\
Leucine arylamidase & 0 & 1 & 2 & 0 & 0 & 1 & 1 & 1 & 1 \\
Trypsin & 0 & 0 & 0 & 1 & 0 & 0 & 0 & 0 & 0 \\
Chemotrypsin & 0 & 1 & 2 & 1 & 0 & 0 & 0 & 0 & 0 \\
$\beta$-Glucuronidase & 0 & 1 & 0 & 0 & 0 & 0 & 0 & 0 & 1 \\
$\alpha$-Glucosidase & 1 & 0 & 1 & 5 & 2 & 2 & 1 & 0 & 1 \\
$\beta$-Glucosidase & 0 & 0 & 0 & 3 & 1 & 0 & 1 & 0 & 3 \\
\hline
\end{tabular}

Table 4. Balances of glucose metabolism by T. flocculiformis Echt ${ }^{\top}$ under oxic and anoxic conditions

Cultures were grown with 4 mM glucose in sulfide-reduced FM, anoxically in FH in anaerobic jars or under air in FH.

\begin{tabular}{|c|c|c|c|c|c|c|c|c|}
\hline \multirow[t]{2}{*}{ Conditions } & \multicolumn{4}{|c|}{ Products formed [mol (mol glucose) $\left.{ }^{-1}\right]$} & \multicolumn{2}{|c|}{ Balances $(\%) *$} & \multirow{2}{*}{$\begin{array}{l}\text { Yield [g dry mass cells } \\
\left.\quad(\text { mol glucose })^{-1}\right]\end{array}$} & \multirow[t]{2}{*}{ Final pH } \\
\hline & Lactate & Formate & Acetate & Ethanol & Carbon & Available $\mathbf{H}$ & & \\
\hline Sulfide reduced & $1 \cdot 13$ & $1 \cdot 02$ & $0 \cdot 35$ & $0 \cdot 39$ & 98 & 96 & $23 \cdot 3$ & $5 \cdot 7$ \\
\hline Anaerobic jar & $1 \cdot 55$ & $0 \cdot 46$ & $0 \cdot 27$ & $0 \cdot 15$ & 99 & 98 & $20 \cdot 5$ & $4 \cdot 9$ \\
\hline Under air & $0 \cdot 91$ & 0.00 & $0 \cdot 90$ & 0.00 & 75 & 90 & $21 \cdot 3$ & $5 \cdot 0$ \\
\hline
\end{tabular}

* Balances were calculated excluding cell matter, which was assumed to have been produced largely from the yeast extract in the medium.

Table 5. Cellular fatty acid compositions of strains expressed as a per cent of the total fatty acids

Strains: 1 , strain $45 \mathrm{AN} 2 ; 2$, strain $37 \mathrm{AN} 3{ }^{* \mathrm{~T}} ; 3$, T. flocculiformis $\mathrm{Echt}^{\mathrm{T}} ; 4$, L. pasteurii $\mathrm{KoTa}^{\mathrm{T}} ; 5$, 'C. allantoicus' NDP; 6, R. palustris Z-7189 ; 7, strain Ben 200; 8, strain Ben 201. ND, Not detected.

\begin{tabular}{|c|c|c|c|c|c|c|c|c|}
\hline Fatty acid & 1 & 2 & 3 & 4 & 5 & $6 \dagger$ & 7 & 8 \\
\hline$C_{12: 0}$ & 12 & 6 & ND & 1 & ND & ND & ND & ND \\
\hline $\mathrm{C}_{14: 0}$ & 57 & 46 & 14 & 28 & 8 & 21 & 14 & 11 \\
\hline$C_{i s o-15: 1}$ & ND & $\mathrm{ND}$ & ND & ND & ND & ND & ND & 1 \\
\hline$C_{16: 0}$ & 14 & 18 & 15 & 16 & 14 & 15 & 24 & 12 \\
\hline $\mathrm{C}_{16: 1}$ & 18 & 27 & 46 & 42 & 44 & 20 & 39 & 50 \\
\hline $\mathrm{C}_{\mathrm{iso-17:1}}$ & ND & ND & 1 & $\mathrm{ND}$ & 1 & ND & 1 & 4 \\
\hline $\mathrm{C}_{18: 0}$ & ND & 2 & 2 & 2 & 2 & 4 & 3 & 1 \\
\hline $\mathrm{C}_{18: 1(\omega 9 c)}$ & ND & 2 & 18 & 6 & 23 & 22 & 16 & 14 \\
\hline $\mathrm{C}_{18: 1(\omega 7 c)}$ & ND & $\mathrm{ND}$ & ND & ND & ND & 2 & ND & ND \\
\hline
\end{tabular}

$\dagger$ Values for R. palustris are taken from Zhilani et al. (1995).

different for each of the different strains are given in Table 2.

All isolates produced detectable levels of esterase lipase (C8), phosphohydrolase and naphthol-AS-B1 phosphohydrolase with the API ZYM system. None expressed $\alpha$-fucosidase, $\alpha$-mannosidase, $N$-acetyl $\beta$ - glucosaminidase, $\beta$-galactosidase, $\alpha$-galactosidase, cystine arylamidase, valine arylamidase or lipase (C4) activities. The differences between their enzyme profiles are shown in Table 3. Where tested, some strains were able to grow at $0-4{ }^{\circ} \mathrm{C}$ and at above $40{ }^{\circ} \mathrm{C}$ (Table 1). Growth was also recorded at $\mathrm{pH}$ values up to 9 and above this value in a few of the strains (Table 1). 


\section{Fermentation of sugars}

All of the strains examined were able to grow with and to ferment glucose (added at $5 \mathrm{mM}$ ) under anoxic conditions, whether grown in $\mathrm{FH}$ in anaerobic jars or in sulfide-reduced FM. All produced lactate, formate, acetate and ethanol as their organic end products of glucose fermentation, and the $\mathrm{pH}$ dropped from an initial value of about 7.3 to values of 5.7-5.9 in FM and $4 \cdot 8-5 \cdot 3$ in FH. All strains, except for Ben 77 , were able to grow with glucose in $\mathrm{FH}$ incubated under oxic conditions. Lactate and acetate were produced by these cultures, and there was a drop in $\mathrm{pH}$, from $7 \cdot 3$ to between $4 \cdot 8$ and $5 \cdot 2$.

\section{Glucose fermentation by $T$. flocculiformis Echt ${ }^{\top}$}

The fermentative behaviour of T. flocculiformis Echt ${ }^{\mathrm{T}}$ was analysed in detail here. It exhibited a mixed-acid fermentation of glucose, producing lactate, formate, acetate and ethanol as its organic end products. At more acidic $\mathrm{pH}$ values, $\mathrm{Echt}^{\mathrm{T}}$ produced less formate, acetate and ethanol, and more lactate (data not shown). Only the L-isomer of lactate was formed. The activity of D-fructose-1,6-bisphosphate-activated lactate dehydrogenase was detected, whereas the activity of D-fructose-1,6-bisphosphate-independent lactate dehydrogenase was not.

Under anoxic conditions T. flocculiformis Echt $^{\mathrm{T}}$ fermented glucose to lactate, formate, acetate and ethanol, both in the FH medium in anaerobic jars and in the sulfide-reduced FM medium. The balances of carbon and available substrate suggest that these fermentation end products, together with biomass production, account for the glucose utilized (Table 4). In contrast, Echt ${ }^{\mathrm{T}}$ produced only acetate and lactate when grown in the presence of $\mathrm{O}_{2}$, and formate and ethanol were not detected under these growth conditions. The carbon balances of oxically incubated cultures suggested that there was a significant production of $\mathrm{CO}_{2}$, whereas the balance of available $\mathrm{H}$ suggests that $\mathrm{O}_{2}$ was reduced (Table 4). Cells grown with glucose under air did not contain cytochromes. Biomass yields from glucose in oxically and anoxically grown cultures were almost identical (Table 4). The slightly higher yields in sulfide-reduced FM may, in fact, be a consequence of the better buffering capacity of that medium (see above and Table 4).

\section{Chemotaxonomic properties}

All of the strains studied possessed the cell wall type A $4 \alpha$ with an L-Lys-D-Asp interpeptide bridge, and their DNA-base compositions fell between 45 and $49 \mathrm{~mol} \% \mathrm{G}+\mathrm{C}$ (Table 1). Fatty-acid analyses revealed some differences between them (Table 5). Thus, while T. flocculiformis $\mathrm{Echt}^{\mathrm{T}}$, 'C. allantoicus' NDP and Ben 200 and Ben 201 had very similar profiles to each other, L. pasteurii $\mathrm{KoTa}_{2}{ }^{\mathrm{T}}$ differed to these strains in its $\mathrm{C}_{14: 0}$ and $\mathrm{C}_{18: 1(\omega 9 c)}$ content. Strains $37 \mathrm{AN} 3{ }^{* \mathrm{~T}}$ and $45 \mathrm{AN} 2$ both had much higher proportions of (a)

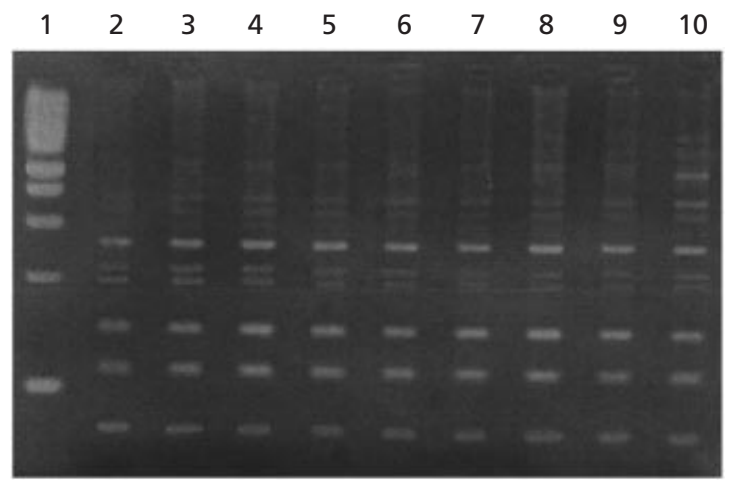

(b)

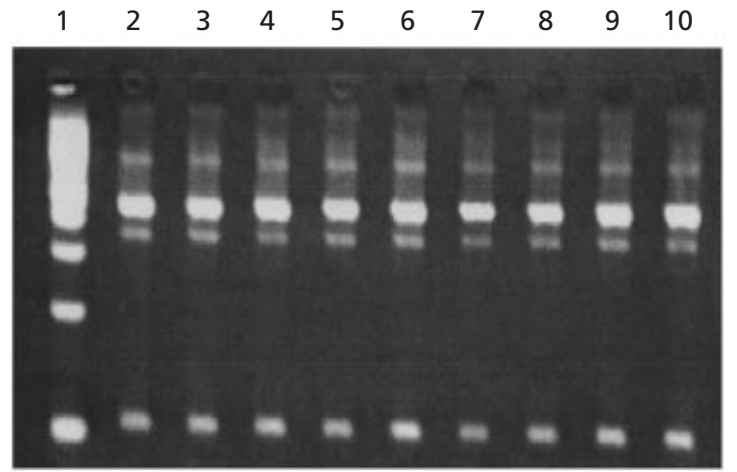

(c)

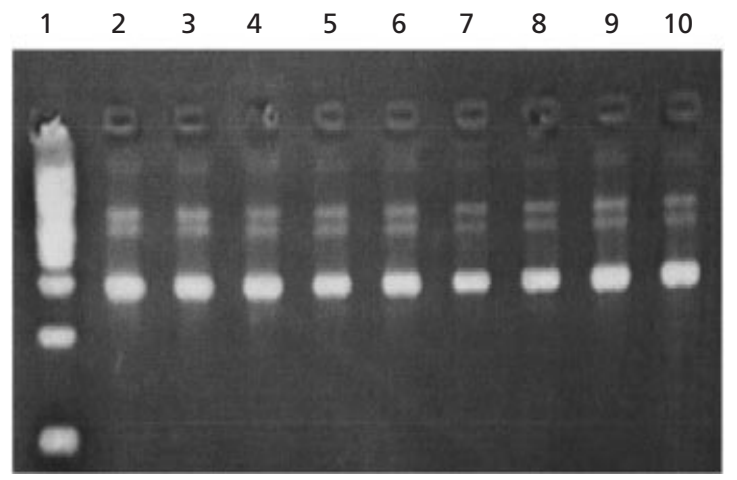

Fig. 3. Fingerprints of fragments of the $16 \mathrm{~S}-23 \mathrm{~S}$ intergenic regions of strains after digestion with restriction endonuclease Sau3Al (a), Mspl (b) and BstUI (c) and separated on agarose gels. Lanes: 1, $100 \mathrm{bp}$ marker; 2, strain 37AN3* ${ }^{* \mathrm{~T}}$; 3, strain 45AN2; 4, strain Ben 77; 5, strain Ben 200; 6, strain Ben 201; 7, strain Ben 206; 8, T. flocculiformis $\mathrm{Echt}^{\top} ;$; , L. pasteurii $\mathrm{KoTa}^{\top}{ }^{\top}$; and 10, 'C. allantoicus' NDP. See text for details.

$\mathrm{C}_{12: 0}$ and $\mathrm{C}_{14: 0}$ than the other strains, and they shared, with $R$. palustris $\mathrm{Z}-7189^{\mathrm{T}}$, a lower $\mathrm{C}_{16: 1}$ content than the rest of the strains.

\section{S-23S rDNA intergenic fingerprinting}

Although different numbers of bands were seen with the different enzymes used, fingerprints obtained after digestion of the 16S-23S PCR products with the endonucleases Sau3AI, MspI and Bst UI (Fig. 3) showed that all of the strains gave identical patterns to each other with each of the three enzymes. Only slight quantitative differences in band intensities between the 


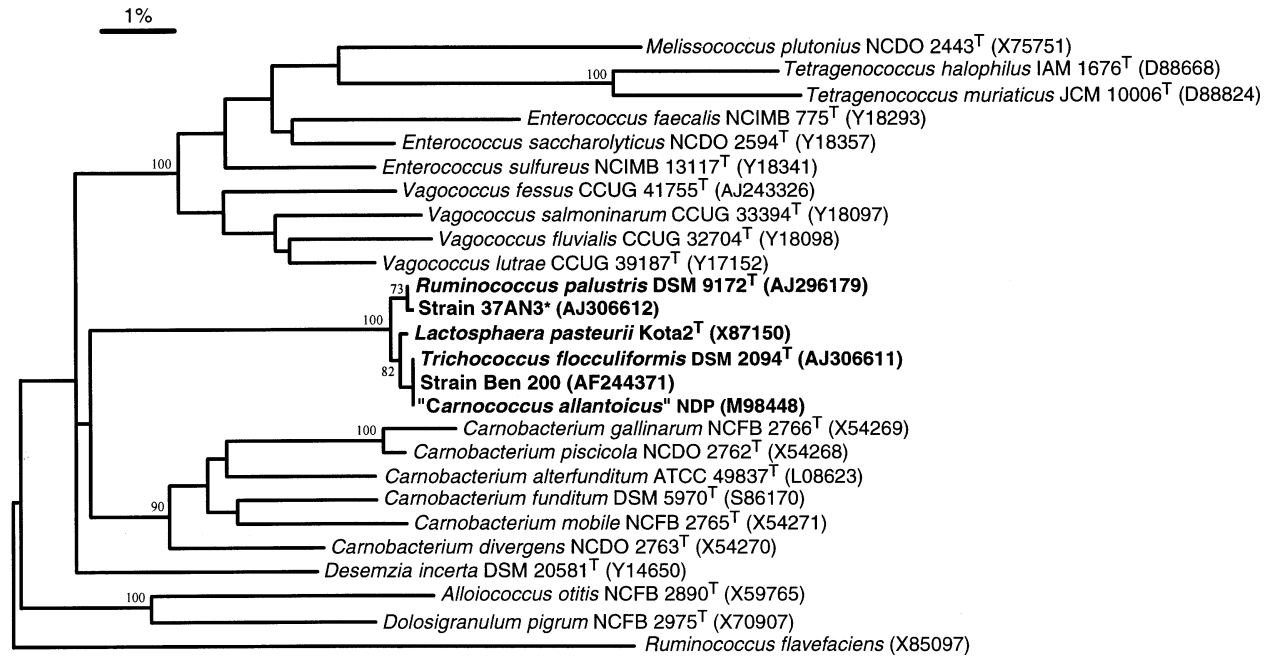

Fig. 4. Tree showing the phylogenetic relationships of strains of the genus Trichococcus in the catalase-negative group of the low-G + C Gram-positive bacteria. The tree, constructed using the neighbour-joining method, was based on approximately $1320 \mathrm{nt}$. Bootstrap values (500 replications) are given at branch points. Bar, 1 substitution per $100 \mathrm{nt}$ positions.

strains were noticed for patterns derived with each enzyme. R. palustris Z-7189 was not analysed.

\section{Phylogenetic relationships between strains}

The almost complete 16S rRNA gene sequences $(>1400 \mathrm{nt}$ ) of these strains were determined. Pairwise analysis revealed that strains $37 \mathrm{AN} 3 * \mathrm{~T}$ and $45 \mathrm{AN} 2$ were $100 \%$ identical, and that strains Ben 77, Ben 200 and Ben 201 were almost identical to each other (99.9-100\% sequence similarity). Sequence searches of the GenBank and RDP libraries also showed that these strains were all members of the low-G + C Grampositive, catalase-negative cocci within the lactic acid group of bacteria. A tree constructed by the neighbourjoining method is shown in Fig. 4. It is evident that strains $37 \mathrm{AN} 3 * \mathrm{~T}$ and $45 \mathrm{AN} 2$ (represented by $37 \mathrm{AN} 3{ }^{* \mathrm{~T}}$ ) form a cluster with $L$. pasteurii $\mathrm{KoTa} 2^{\mathrm{T}}$ and $R$. palustris Z-7189 ${ }^{\mathrm{T}}$. More specifically, 37AN3*T shares a branching node with $L$. pasteurii, but this relationship was not statistically significant (recovered in $52 \%$ of the re-samplings). Strains Ben 77, Ben 200 and Ben 201, as exemplified by Ben 200, were most closely related to T. flocculiformis Echt ${ }^{\mathrm{T}}$ and 'Carnococcus allantoicus' NDP. However, all of the strains demonstrated a 16S rRNA sequence similarity of greater than $99 \%$, forming a tight robust cluster that was supported by a significant bootstrap re-sampling value of $100 \%$. All of the major groupings were confirmed using maximum-parsimony analysis (data not shown).

\section{DNA-DNA hybridization between strains}

DNA hybridizations between the different strains revealed that $T$. flocculiformis Echt ${ }^{\mathrm{T}}$, ' $C$. allantoicus' NDP, Ben 77, Ben 200 and Ben 201 had hybridization values displaying more than $70 \%$ similarity with each other. Conversely, L. pasteurii $\mathrm{KoTa} 2^{\mathrm{T}}$, R. palustris Z$7189^{\mathrm{T}}$, and strains $37 \mathrm{AN} 3{ }^{* \mathrm{~T}}$ and $45 \mathrm{AN} 2$ showed DNA hybridization values of less than $70 \%$ with any of the other strains for which data were obtained. Thus, the values for $L$. pasteurii $\mathrm{KoTa}^{\mathrm{T}} / R$. palustris $\mathrm{Z}-7189^{\mathrm{T}}$, L. pasteurii $\mathrm{KoTa}^{\mathrm{T}} /$ C. allantoicus $\mathrm{NDP}$, L. pasteurii $\mathrm{KoTa}^{\mathrm{T}} /$ Ben 201 and L. pasteurii $\mathrm{KoTa}^{\mathrm{T}} / 37 \mathrm{AN} 3^{* \mathrm{~T}}$ were $40 \cdot 4,56,59 \cdot 5$ and $57.9 \%$, respectively. Those for $R$. palustris Z-7189 ${ }^{\mathrm{T}}$ /Ben $201, R$. palustris $\mathrm{Z}-7189^{\mathrm{T}}$ / $37 \mathrm{AN} 3 * \mathrm{~T}, 37 \mathrm{AN} 3 * \mathrm{~T} / \mathrm{Ben} 201$ and 45AN2/Ben 201 were $35.8,34 \cdot 4,53.3$ and $51 \cdot 7 \%$, respectively, whereas that for $37 \mathrm{AN} 3 * \mathrm{~T} / 45 \mathrm{AN} 2$ was $97 \cdot 8 \%$.

\section{DISCUSSION}

T. flocculiformis $\mathrm{Echt}^{\mathrm{T}}$, L. pasteurii $\mathrm{KoTa}^{\mathrm{T}}$, ' $C$. allantoicus' NDP, R. palustris Z-7189 ${ }^{\mathrm{T}}$, and strains $37 \mathrm{AN} 3{ }^{* \mathrm{~T}}$ and $45 \mathrm{AN} 2$, together with the ' $N$. limicola' I strains Ben 77, Ben 200 and Ben 201, are all aerotolerant, fermentative bacteria with similar fermentation end products, and which probably have similar biochemical pathways. Two different fermentation pathways seem to be operating under anaerobic conditions in T. flocculiformis Echt ${ }^{\mathrm{T}}$, chosen as representative of the strains studied here and for comparison with L. pasteurii KoTa $2^{\mathrm{T}}$, whose fermentation behaviour has been examined previously by Janssen et al. (1995). Both species are very similar in their fermentation behaviour. In the first pathway in $T$. flocculiformis Echt $^{\mathrm{T}}$, a homolactic fermentation results in the formation of (theoretically) 2 mol lactate (mol glucose metabolized) ${ }^{-1}$. In this pathway, electrons arising from the oxidation of $1 \mathrm{~mol}$ of glucose to $2 \mathrm{~mol}$ of pyruvate are used to reduce $2 \mathrm{~mol}$ of pyruvate to 2 mol of lactate, via the lactate dehydrogenase. The second pathway, which is less active at more acidic $\mathrm{pH}$ 
values, leads to the production of formate, acetate and ethanol. In this pathway, electrons arising from the oxidation of $1 \mathrm{~mol}$ of glucose to $2 \mathrm{~mol}$ of pyruvate are used to reduce $1 \mathrm{~mol}$ of pyruvate to $1 \mathrm{~mol}$ of ethanol (via acetyl-CoA), leaving $1 \mathrm{~mol}$ of pyruvate to be metabolized to acetate (also via acetyl-CoA). In this pathway, the oxidation of pyruvate to acetyl-CoA leads to the production of $2 \mathrm{~mol}$ of formate, and the pathway is balanced by the absence of lactate formation. These two pathways appear to operate simultaneously in $T$. flocculiformis Echt ${ }^{\mathrm{T}}$, as they do in $L$. pasteurii KoTa2 ${ }^{\mathrm{T}}$ (Janssen et al., 1995). In oxically incubated cultures, no ethanol was produced and an increase in acetate production was observed. This indicates that electrons normally disposed of in the reductive pathway from acetyl-CoA to ethanol may instead flow to $\mathrm{O}_{2}$, allowing more acetyl-CoA flow to acetate. In addition, the lack of formate production in aerobically incubated cultures suggests that electrons also flow to $\mathrm{O}_{2}$ at the steps normally resulting in formate production. The production of lactate did not appear to be influenced by the presence of $\mathrm{O}_{2}$, nor was there evidence that acetate (or acetyl-CoA) is oxidized to $\mathrm{CO}_{2}$.

If it is assumed that formate is oxidized to $\mathrm{CO}_{2}$ (or that $\mathrm{CO}_{2}$ is formed directly from pyruvate), and that the carbon flux through this pathway is the same as in the formate-producing pathway under anoxic conditions, the estimated $\mathrm{CO}_{2}$ production would account for $17-21 \%$ of the carbon balance, and would therefore increase the carbon balance under oxic conditions to $92-96 \%$. Since there was no yield increase in the presence of $\mathrm{O}_{2}$, and no cytochromes were detected in oxically grown cells, ATP production linked to $\mathrm{O}_{2}$ respiration does not occur. It therefore seems that $T$. flocculiformis Echt $^{\mathrm{T}}$ uses $\mathrm{O}_{2}$ as a terminal electron acceptor as a means of disposing of electrons, without any ATP formation linked to electron transport. Such a transfer of electrons to $\mathrm{O}_{2}$ by lactic acid bacteria has been described previously (van Beelen et al., 1986; Fukui et al., 1988). Some small increase in ATP formation would result as a consequence of increased flow through the acetate-producing pathway with concomitant phosphotransacetylase-dependent ATP formation in the absence of the need for ethanol formation as a route for disposing of electrons arising from glucose oxidation to pyruvate, but this may be offset by a higher maintenance energy requirement to repair oxidative damage under air.

The data presented here support the view that all of the isolates examined in this study are sufficiently similar in their phenotypic, chemotaxonomic and phylogenetic attributes to be considered members of the same genus in the low-G + C Gram-positive bacteria (Table 1, Fig. 4). As well as being aerotolerant, all of the strains are oxidase- and catalase-negative, possess the same cell-wall composition and have very similar $\mathrm{mol} \% \mathrm{G}+\mathrm{C}$ values. They also have almost identical 16S rRNA sequences to each other ( $>99 \%$ sequence similarity), and all (except for R. palustris Z $-7189^{\mathrm{T}}$, which was not included in the analysis) give identical fingerprints after digestion with three different restriction endonucleases of their $16 \mathrm{~S}-23 \mathrm{~S}$ intergenic spacer regions. This is despite the differences in their cell morphologies and arrangements suggested from their original descriptions, which have been revealed here as inadequate, since all of the strains appear to be able to grow either in chains or as single or paired cells, often highly irregular in shape and size, depending on the culture conditions used (Figs 1 and 2).

Apart from these considerable shared phenotypic properties, some small differences were recorded among the strains. For example, only $L$. pasteurii KoTa $2^{\mathrm{T}}$ and strains $37 \mathrm{AN} 3{ }^{* \mathrm{~T}}$ and $45 \mathrm{AN} 2$ grew with L-tartrate, an unusual ability considered by Janssen et al. (1995) to be distinctive of L. pasteurii KoTa2 ${ }^{\mathrm{T}}$. Other differences among the strains were apparent in their abilities to grow on allantoin and L-malate (Table 1), and their fatty-acid profiles also showed distinctive features (Table 5). It was not possible to distinguish between the different strains using phenotypic characters, and the phenotypic and phylogenetic data together suggested that the strains all belonged to a single species. However, the DNA-DNA hybridization data do not support this view. Similarity values would suggest that $T$. flocculiformis $\mathrm{Echt}^{\mathrm{T}}$, 'C. allantoicus' NDP and strains Ben 200, Ben 201 and Ben 77 should all be placed in the same genomic species (similarity values of $>70 \%$ ), whereas strains $37 \mathrm{AN} 3 * \mathrm{~T}$ and $45 \mathrm{AN} 2$ (similarity value of $98 \%$ ) should be placed in a separate genomic species. On this evidence, both L. pasteurii $\mathrm{KoTa}^{\mathrm{T}}$ and $R$. palustris $\mathrm{Z}-7189^{\mathrm{T}}$, despite being $99 \%$ similar to all of the other strains on the basis of their $16 \mathrm{~S}$ rRNA sequences, each belong to separate genomic species.

Other bacteria have been described with very high or identical 16S rRNA sequences, which after DNADNA hybridization determinations emerged as separate species (Fox et al., 1992; Yassin et al., 1997; Maszenan et al., 2000). For example, Sporosarcina psychrophila W16A $\mathrm{A}^{\mathrm{T}}$ and W5 and Sporosarcina globispora $\mathrm{W} 25^{\mathrm{T}}$ exhibited more than $99.5 \%$ similarity in their 16S rRNA sequence, yet DNA-DNA hybridization values between them were too low (23 and $50 \%$ ) for them to be considered as the same species, even though they exhibited very similar phenotypic properties (Fox et al., 1992; Yoon et al., 2001). Yassin et al. (1997) also reported that the high levels of $16 \mathrm{~S}$ rDNA sequence similarity (>99\%) between Tsukamurella strains were not supported by DNA-DNA hybridization data. These experiences emphasize that $16 \mathrm{~S} \mathrm{rDNA}$ genes may be conserved between members of closely related bacterial species and that they cannot be used to differentiate between them at the species level (Fox et al., 1992; Goodfellow, 2000).

Although the genus name Trichococcus predates the genus name Lactosphaera, it is not really a descriptive name for this group of bacteria (e.g. Figs 1 and 2). The reasons why cell morphologies in this group of bacteria 
vary so much are not known, but they have particular relevance when using microscopic identification methods to detect these bacteria in activated sludge.

This study suggests that this genus should include four species, namely Trichococcus flocculiformis, to include T. flocculiformis $\mathrm{Echt}^{\mathrm{T}}$ (Scheff et al., 1984a), 'C . allantoicus' NDP, Ben 77, Ben 200 and Ben 201, Trichococcus pasteurii, to include L. pasteurii KoTa2 ${ }^{\mathrm{T}}$, Trichococcus palustris, to include $R$. palustris Z-7189 ${ }^{\mathrm{T}}$, and Trichococcus collinsii, to include strains 37AN3*T and 45AN2. The descriptions of these four species are given below.

\section{Emended description of the genus Trichococcus (Scheff et al. 1984b)}

Spherical to ovoid, sometimes olive-shaped cells with a mean cell diameter of $1.0-1.5 \mu \mathrm{m}$ and a mean cell length of $1 \cdot 0-2.5 \mu \mathrm{m}$, usually arranged in chains but sometimes appearing as single or paired cocci.

Aerotolerant, fermentative organisms in the low- $\mathrm{G}+\mathrm{C}$ Gram-positive bacteria. Cells grow with glucose to produce lactate and acetate oxically, and to produce lactate, acetate, formate and ethanol anoxically. Cells also grow with sucrose and lactose, with acid production. All members of the genus utilize arbutin, cellobiose, D-fructose, $\alpha$-D-glucose, D-mannose, salicin, sucrose and pyruvate with the BIOLOG system. None of the following substrates are utilized: $\beta$ cyclodextrin, inulin, Tween 40 , Tween 80 , L-arabinose, D-arabitol, L-fucose, D-galacturonic acid, D-gluconic acid, myo-inositol, methyl $\alpha$-D-glucoside, methyl $\alpha$-Dmannoside, sedoheptulosan, D-sorbitol, D-tagatose, xylitol, D-xylose, acetic acid, $\alpha$-hydroxybutyrate, $\beta$-hydroxybutyrate, $\gamma$-hydroxybutyrate, $\beta$-hydroxyphenylacetate, 2-oxoglutarate, 2-oxovalerate, lactamide, D-lactic acid methyl ester, L-lactic acid, D-malic acid, L-malic acid, monomethylsuccinic acid, propionic acid, succinamic acid, $N$-acetylglutamic acid, alaninamide, D-alanine, L-alanine, L-alanylglycine, L-asparagine, L-glutamic acid, glycyl-L-glutamic acid, L-pyroglutamic acid, L-serine, putrescine, 2,3-butanediol, glycerol, inosine, thymidine, adenosine 5 '-monophosphate, thymidine 5'-monophosphate, uridine 5'-monophosphate, fructose 6-phosphate, glucose 1phosphate, glucose 6-phosphate, DL- $\alpha$-glycerol phosphate. No indole is produced. The DNA base compositions range from 45 to $49 \mathrm{~mol} \% \mathrm{G}+\mathrm{C}$. The peptidoglycan type is type A4 $\alpha$, L-Lys-D-Asp (A 11.31). The natural habitats of members of the genus are activated sludge, soil and sediment. The type species of the genus is Trichococcus flocculiformis $\mathrm{Echt}^{\mathrm{T}}$.

\section{Emended description of Trichococcus flocculiformis (Scheff et al. 1984b)}

T. flocculiformis is a previously described organism, originally isolated from bulking sludge in Germany (Scheff et al., 1984a). Results in this study suggest that ' $N$. limicola' I (strains Ben 200, Ben 201 and Ben 77) and ' $C$. allantoicus' NDP should be merged into this species, even though some of these strains exhibit morphologies which may differ from the original descriptions of cocci in chains. Under certain culture conditions, T. flocculiformis Echt ${ }^{\mathrm{T}}$ grows as single cells or as paired, rod-shaped cells. In addition to the properties given in the genus description above and the original species description, members of this species have the following characteristics. Cells are spherical to ovoid; some strains grow as olive-shaped cells. Colonies on SR2A agar are white, opaque, circular and convex. All strains show no growth with L-tartrate. Only some strains grow on allantoin and L-malate. Only some produce acid from inositol, sorbitol, mannitol, raffinose and adonitol; only some reduce nitrate and are urease positive. Fatty acid composition is $\mathrm{C}_{14: 0}$ $(8-14 \%), \mathrm{C}_{16: 0}(12-24 \%), \mathrm{C}_{16: 1}(39-50 \%), \mathrm{C}_{\text {iso-17:1 }}$ $(1-4 \%), C_{18: 0}(1-3 \%)$ and $C_{18: 1(\omega 9 c)}(14-23 \%)$. The $\mathrm{G}+\mathrm{C}$ content is $47-49 \mathrm{~mol} \%$. Isolated from activated sludge in different parts of the world or from duckpond sediment in the USA. The type strain of

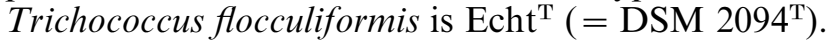

\section{Description of Trichococcus collinsii sp. nov.}

Trichococcus collinsii (coll.ins'i.i. N.L. gen. n. collinsii referring to M. D. Collins, a contemporary English microbiologist who has contributed significantly to our understanding of the systematics of the lactic acid bacteria).

This species is proposed to include strains $37 \mathrm{AN} 3 * \mathrm{~T}$ and 45AN2, isolated from a hydrocarbon-spill site (Geig et al., 1999). In addition to the properties given in the genus description above, members of this species have the following characteristics. They can grow with citrate, L-malate, allantoin and L-tartrate, and produce acid from mannitol. Only strain $37 \mathrm{AN} 3^{* \mathrm{~T}}$ produces acid from inositol, sorbitol, raffinose and adonitol. Fatty acid compositions show this species has a distinctively high $\mathrm{C}_{14: 0}$ fatty acid content, which ranges between 46 and $57 \%$. Other major fatty acids are $\mathrm{C}_{12: 0}$ $(6-12 \%)$ and $\mathrm{C}_{16: 0}(14-18 \%)$. The type strain of Trichococcus collinsii is $37 \mathrm{AN} 3^{* \mathrm{~T}}\left(=\mathrm{DSM} 14526^{\mathrm{T}}=\right.$ ATCC BAA-296 ${ }^{\mathrm{T}}$ ).

\section{Emended description of Trichococcus pasteurii (Schink 1985; emend. Janssen et al. 1995) comb. nov.}

$T$. pasteurii was originally transferred from the genus Ruminococcus (R. pasteurii; Schink, 1984) by Janssen et al. (1995) into the genus Lactosphaera, as $L$. pasteurii, as this organism has several distinctive properties, including the ability to produce significant amounts of lactic acid and being aerotolerant. Its description is the same as that for L. pasteurii $\mathrm{KoTa}_{2}{ }^{\mathrm{T}}$, as given by Janssen et al. (1995), except that cells usually appear as single regularly shaped and sized cocci, except when growing in R2A broth, when they become irregular in shape and size and are arranged in short chains. The strain grows with L-tartrate but not 
with allantoin, and produces acid from inositol, mannitol, sorbitol, raffinose and adonitol. Cellular fatty acid composition is $\mathrm{C}_{12: 0}(1 \%), \mathrm{C}_{14: 0}(28 \%)$, $\mathrm{C}_{16: 0}(16 \%), \mathrm{C}_{16: 1}(42 \%), \mathrm{C}_{18: 0}(2 \%)$ and $\mathrm{C}_{18: 1(\omega 9 c)}$ $(6 \%)$. The type strain of Trichococcus pasteurii is $\operatorname{KoTa}^{\mathrm{T}}\left(=\operatorname{DSM} 2381^{\mathrm{T}}=\right.$ ATCC $\left.35945^{\mathrm{T}}\right)$.

\section{Emended description of Trichococcus palustris (Zhilina et al. 1997) comb. nov.}

$T$. palustris was originally described as $R$. palustris Z$7189^{\mathrm{T}}$ (Zhilina et al., 1995). 16S rRNA sequence data suggest that this organism should be merged into the genus Trichococcus, but DNA-DNA hybridization data suggest it is a separate species, namely T.palustris. The features of this organism are those given by Zhilina et al. (1995), except that it is an aerotolerant fermentative organism and is not anaerobic (Zhilina et al., 1995). The type strain of Trichococcus palustris is Z-7189 ${ }^{\mathrm{T}}$ (= DSM 9172 $)$.

\section{ACKNOWLEDGEMENTS}

We wish to acknowledge the financial support of the Australian Research Council and La Trobe University. J. R. Liu was supported by a PhD scholarship from La Trobe University.

\section{REFERENCES}

Barker, H. A. (1943). Streptococcus allantoicus and the fermentation of allantoin. J Bacteriol 46, 251-259.

Bergmeyer, H. U. (1974). Methoden der Enzymatischen Analyse, 3rd edn. Weinheim: Verlag Chemie.

Bond, P. L., Hugenholtz, P., Keller, J. \& Blackall, L. L. (1995). Bacterial community structures of phosphate-removing and nonphosphate-removing activated sludges from sequencing batch reactors. Appl Environ Microbiol 61, 1910-1916.

Ehrlich, G. G., Goerlitz, D. F., Bourell, J. H., Eisen, G. V. \& Godsey, E. M. (1981). Liquid chromatographic procedure for fermentation product analysis in the identification of anaerobic bacteria. Appl Environ Microbiol 42, 878-885.

Eikelboom, D. H. (2000). Process Control of Activated Sludge Plants by Microscopic Investigation. London: IWA Publishing.

Felsenstein, J. (1989). PHYLIP-Phylogeny inference package (version 3.2). Cladistics 5, 164-166.

Fox, G. E., Wisotzkey, J. D. \& Jurtshuk, R., Jr (1992). How close is close: 16S rRNA sequence identity may not be sufficient to guarantee species identity. Int J Syst Bacteriol 42, 166-170.

Fukui, K., Kato, K., Kodama, T., Ohta, H., Shimamoto, T. \& Shimono, T. (1988). Kinetic study of a change in intracellular ATP level associated with aerobic catabolism of ethanol by Streptococcus mutans. J Bacteriol 170, 4589-4593.

Gieg, L. M., Kolhatkar, R. V., Mclnerney, M. J., Tanner, R. S., Harris, S. H., Sublette, K. L. \& Suflita, J. M. (1999). Intrinsic bioremediation of petroleum hydrocarbons in a gas condensatecontaminated aquifer. Environ Sci Technol 33, 2550-2560.

Goodfellow, M. (2000). Microbial systematics: background and uses. In Applied Microbial Systematics, pp. 1-18. Edited by F. G. Priest \& M. Goodfellow. Dordrecht: Kluwer Academic.

Gürtler, V. \& Stanisich, V. A. (1996). New approaches to typing and identification of bacteria using the 16S-23S rDNA spacer region. Microbiology 142, 3-16.

Janssen, P. H. (1998). Pathway of glucose catabolism by strain VeGlc2, an anaerobe belonging to the Verrucomicrobiales lineage of bacterial descent. Appl Environ Microbiol 64, 4830-4833.

Janssen, P. H., Evers, S., Rainey, F. A., Weiss, N., Ludwig, W., Harfoot, C. G. \& Schink, B. (1995). Lactosphaera gen. nov., a new genus of lactic acid bacteria, and transfer of Ruminococcus pasteurii Schink (1984) to Lactosphaera pasteurii comb. nov. Int J Syst Bacteriol 45, 565-571.

Janssen, P. H., Schuhmann, A., Morschel, E. \& Rainey, F. A. (1997). Novel anaerobic ultramicrobacteria belonging to the Verrucomicrobiales lineage of bacterial descent isolated by dilution culture from anoxic rice paddy soil. Appl Environ Microbiol 63, 1382-1388.

Jenkins, D., Richard, M. G. \& Daigger, G. T. (1993). Manual on the Causes and Control of Activated Sludge Bulking and Foaming. Boca Raton, FL: Lewis Publishers.

Lamed, R. \& Zeikus, J. G. (1980). Glucose fermentation pathway of Thermoanaerobium brockii. J Bacteriol 141, 1251-1257.

Lipman, D. J. \& Pearson, W. R. (1985). Rapid and sensitive protein similarity searches. Science 227, 1435-1441.

Liu, J.-R., Burrell, P., Seviour, E. M., Soddell, J. A., Blackall, L. L. \& Seviour, R. J. (2000). The filamentous bacterial morphotype 'Nostocoida limicola' I contains at least two previously described genera in the low G+C gram positive bacteria. Syst Appl Microbiol 23, 528-534.

Liu, J.-R., McKenzie, C. A., Seviour, E. M., Webb, R. I., Blackall, L. L., Saint, C. P. \& Seviour, R. J. (2001). Phylogeny of the filamentous bacterium 'Nostocoida limicola' III from activated sludge. Int J Syst Evol Microbiol 51, 195-202.

Maszenan, A. M., Seviour, R. J., Patel, B. K. C., Schumann, P., Burghardt, J., Tokiwa, Y. \& Stratton, H. M. (2000). Three isolates of novel polyphosphate-accumulating Gram-positive cocci, obtained from activated sludge, belong to a new genus, Tetrasphaera gen. nov., and description of two new species, Tetrasphaera japonica sp. nov. and Tetrasphaera australiensis sp. nov. Int J Syst Evol Microbiol 50, 593-603.

Miller, L. T. (1982). Single derivatization method for routine analysis of whole-cell fatty acid methyl esters. J Clin Microbiol 16, 584-586.

Nicholas, K. B., Nicholas, H. B., Jr \& Deerfield, D. W., II (1997). GENEDOC: analysis and visualization of genetic variation. EMB News 4 , 14.

Rasmussen, S. W. (1995). DNATOOLS: a software package for DNA sequence analysis. Copenhagen: Carlsberg Laboratory.

Reasoner, M. G. \& Geldreich, E. E. (1985). A new medium for the enumeration and subculture of bacteria from potable water. Appl Environ Microbiol 49, 1-7.

Sassar, M. (1990). Identification of bacteria by gas chromatography of cellular fatty acids. In MIDI Technical Note 101. Newark: MIDI.

Scheff, G., Salcher, O. \& Lingens, F. (1984a). Trichococcus flocculiformis gen. nov. sp. nov. A new gram-positive filamentous bacterium isolated from bulking sludge. Appl Microbiol Biotechnol 19, 114-119.

Scheff, G., Salcher, O. \& Lingens, F. (1984b). Trichococcus flocculiformis gen. nov., sp. nov. In Validation of the Publication of New Names and New Combinations Previously Effectively Published Outside the $I J S B$, List no. 15. Int J Syst Bacteriol 34, 355-357.

Schink, B. (1984). Fermentation of tartrate enantiomers by anaerobic bacteria, and description of two new species of strict anaerobes, Ruminococcus pasteurii and Ilyobacter tartaricus. Arch Microbiol 139, 409-414.

Schink, B. (1985). Ruminococcus pasteurii sp. nov. In Validation of the Publication of New Names and New Combinations Previously Effectively Published Outside the IJSB, List no. 18. Int J Syst Bacteriol 35, 375-376.

Schumann, P., Prauser, H., Rainey, F. A., Stackebrandt, E. \& Hirsch, P. (1997). Friedmanniella antarctica gen. nov., sp. nov., an LLdiaminopimelic acid-containing actinomycete from Antarctic sandstone. Int J Syst Bacteriol 47, 278-283.

Stackebrandt, E., Schumann, P., Swiderski, J. \& Weiss, N. (1999). Reclassification of Brevibacterium incertum (Breed 1953) as Desemzia incerta gen. nov., comb. nov. Int J Syst Bacteriol 49, 185-188.

Tanner, R. S. (1997). Cultivation of bacteria and fungi. In Manual of Environmental Microbiology, pp. 52-60. Edited by C. J. Hurst, G. R. 
Knudsen, M. J. McInerney, L. D. Stetzenbach \& M. V. Walter. Washington, DC: American Society for Microbiology.

van Beelen, P., van der Hoeven, J. S., de Jong, M. H. \& Hoogendoorn, H. (1986). The effect of oxygen on the growth and acid production of Streptococcus mutans and Streptococcus sanguis. FEMS Microbiol Ecol 38, 25-30.

van Veen, W. L. (1973). Bacteriology of activated sludge, in particular the filamentous bacteria. Antonie Leeuwenhoek 39, 189-205.

Yassin, A. F., Rainey, F. A., Burghardt, J. \& 8 other authors (1997). Tsukamurella tyrosinosolvens sp. nov. Int J Syst Bacteriol 47, 607-614.

Yoon, J.-H., Lee, K.-C., Weiss, N., Kho, Y. H., Kang, K. H. \& Park, Y.H. (2001). Sporosarcina aquimarina sp. nov., a bacterium isolated from seawater in Korea, and transfer of Bacillus globisporus (Larkin and
Stokes 1967), Bacillus psychrophilus (Nakamura 1984) and Bacillus pasteurii (Chester 1898) to the genus Sporosarcina as Sporosarcina globispora comb. nov., Sporosarcina psychrophila comb. nov. and Sporosarcina pasteurii comb. nov., and emended description of the genus Sporosarcina. Int J Syst Evol Microbiol 51, 1079-1086.

Zhilina, T. N., Kotsyurbenko, O. R., Osipov, G. A., Kostrinka, N. A. \& Zavarzin, G. A. (1995). Ruminococcus palustris sp. nov. - a psychroactive anaerobic organism from a swamp. Microbiology (English translation of Mikrobiologiya) 64, 674-680.

Zhilina, T. N., Kotsyurbenko, O. R., Osipov, G. A., Kostrinka, N. A. \& Zavarzin, G. A. (1997). Ruminococcus palustris sp. nov. In Validation of the Publication of New Names and New Combinations Previously Effectively Published Outside the IJSB, List no. 60. Int J Syst Bacteriol 47, 242. 